\title{
A summary of thinking on measuring the value of marketing
}

\author{
RECEIVED (IN REVISED FORM): 5 FEBRUARY, 2000
}

Bruce H. Clark

Associate Professor, Marketing, Northeastern University, 202 Hayden Hall, Boston MA

02 II5, USA; Tel: + I 617373 4783; Fax: + I 617373 8366; e-mail:

b.clark@neu.edu

Bruce H. Clark

is an Associate

Professor of

Marketing at

Northeastern

University. A

former software

and direct

marketing

executive, he

writes and teaches

about competitive

marketing strategy

and marketing

performance

measurement.
Abstract

Scholars have been developing and evaluating schemes for measuring the performance of marketing activities for the past halfcentury. This paper traces the evolution of research in marketing performance measurement. It discusses the movement from financial measurement to non-financial measures, and examines the marketing asset and customer-focused approaches to performance measurement. Managers desiring a comprehensive picture of marketing performance should draw on a number of these perspectives. All measures should be evaluated in the context of the organisation's strategy and customer and competitor benchmarks.

Understanding the value of marketing to the success of the firm has never been more important. Firms have been demanding more accountability of marketing and marketers for a number of reasons.

First, many firms reached the point of diminishing returns in achieving benefits from cost cutting in the first half of the 1990s, leading them to look to marketing to provide more revenue growth. Cost reductions in manufacturing and administration also had the effect of making the marketing spend a larger portion of the overall company budget, drawing the attention of company accountants. ${ }^{1}$ Simultaneously, investors have been demanding more information regarding the marketing activities of companies. ${ }^{2,3}$ Finally, the growth of multidimensional performance measurement schemes such as the Balanced Scorecard and associated strategy maps have led both researchers and practitioners to consider what marketing performance measures, if any, belong in the mix. ${ }^{4,5}$ The result of all these concerns has led to calls for improved research in both the USA and the UK. ${ }^{6-8}$

The urgency of current needs sometimes obscures the fact that there is a long history of research on how to measure the performance of marketing. ${ }^{9}$ Over decades the field has undergone a revolution in philosophy and methods, sometimes paralleling evolution of measurement within firms themselves. This paper will review the history of research in marketing performance measurement with an eye to understanding what managers may learn from the academic endeavour in this area. 


\section{DEFINITIONS}

One of the great obstacles to successful measurement of marketing performance is the multidimensional nature of the marketing construct itself. 'Marketing' can be conceptualised in a number of different ways, and what is measured depends on what it is thought to be.

A fundamental and growing dichotomy in research and practice is the distinction between marketing as an organisational function (eg the marketing department with its budget) and the marketing as a process for the firm as a whole (eg activities that facilitate the link between the customer and the firm). The elevation of customers as a corporate concern has increased attention to the latter view. Indeed, Nigel Piercy observes that marketing is in some sense too important to leave to the marketers. ${ }^{10}$

A second distinction is the organisational level at which marketing activities occur. At the highest level, one can think of marketing across the entire corporation and its impact on corporate reputation. Tim Ambler refers to this as 'pan-company' marketing. ${ }^{11}$ In most companies of any size, one can then look at the activities of particular divisions or strategic business units. Within these units one might look at the performance of particular products or services. Finally, one can look at the efficiency and effectiveness of particular marketing subfunctions such as advertising or distribution.

This paper will focus on marketing as a process, how the firm manages the link between its activities and customers, regardless of whether this work is the province of the marketing department. The discussion will also be restricted to the evaluation of pancompany marketing and marketing for particular divisions. The large literatures examining the performance of marketing subfunctions will generally be ignored.

\section{MARKETING PRODUCTIVITY ANALYSIS}

Historically, many firms did (and some still do) no separate evaluation of marketing at all. When firms and researchers did move beyond this stage, most focused on attempting to evaluate the financial impact of marketing activities - 'given our marketing, how much money did we make?' Linking strongly to the accounting and finance literatures, these approaches were typically quantitative and oriented toward financial ratios such as return on sales, return on investment, and expenditures as a percentage of sales. Work in this area was often called marketing productivity analysis, as it attempted to show the efficiency with which marketing resources were deployed.

While research and practice continue, much of the seminal work in this area occurred in the 1960s and 1970s. Writers such as Charles Sevin and Sam Goodman wrote detailed, insightful books on applying profitability and efficiency analyses to 
marketing. ${ }^{12,13}$ Later articles and books focused on the marketing/accounting interface and insights from finance. Stanley Shapiro and V.H. Kirpalani summarised much of this stream in their anthology on marketing effectiveness. ${ }^{14}$ More sophisticated approaches attempted to look at the long-term cash flow generated by marketing strategies, leading some to talk about the net present value of marketing. ${ }^{15}$

Research on managerial practice suggests that financial measures such as sales and profit are the most common means of measuring the value of marketing. ${ }^{16}$ Managerially, there is much to commend in this approach. Even if crude, attempting to understand the profit impact of marketing activities is a fundamental first step to understanding marketing performance. Understanding the real costs and returns from investments in marketing is an area in which accountants and marketers have much to learn from one another.

The fear in relying upon profitability measures, however, is that financial measures are essentially static and backward looking. The profits a firm sees today are the result of past marketing efforts stretching over years, if not decades. While the longterm cash flow approach to measurement of marketing performance does eliminate the static objection, estimates of this kind are still difficult to make. Generally, financial measures may be poor indicators of the future. While measuring the financial impact of marketing activities is a necessary step to understanding the value of marketing, it is not sufficient.

\section{MOVING BEYOND PROFIT}

Over the course of the 1980s, nonfinancial measures of marketing success received much attention. Supplements to traditional sales and profitability analysis, these measures were thought to indicate more strongly the longterm prospects of the organisation.

\section{Market share}

Perhaps the most influential measure advocated at this time was unit market share. Based on research by the Boston Consulting Group and the Profit Impact of Market Strategies project, and fuelled by competition from Japanese firms that emphasised market share as a measure, firms ferociously competed to achieve high unit market share that would lead to economies of scale and long-run profitability. ${ }^{17,18}$

In retrospect, emphasis on market share as a performance measure has proved problematic. While economies of scale in industries such as motorcycles and semiconductors motivated the argument, more rigorous research has cast doubt on a universal link between market share and long-term profitability. ${ }^{19,20}$ The spectacular failure of Japan, Inc. in the 1990s has also diminished the lustre of this approach to business. Research on managerial decision-making now suggests that the exclusive focus on beating competitors implied by market share measurement 
can actually lead to economically irrational behaviour by firms. ${ }^{21}$ Further, market share measures assume the firm has identified the correct competitive set, which is a non-trivial task. ${ }^{22}$

Managerially, unit market share is therefore a crude measure that should be used with caution. It is best used as a check on sales growth figures. Company sales growth should be placed in the context of industry sales growth: the prognosis for firms growing faster than their industry (rising unit share) differs from the prognosis for those growing slower than their industry (falling unit share). Another useful way to use market share is to compare value market share (eg in Euros) to unit market share. This allows the firm to understand how relative price might be affecting unit share. ${ }^{23}$ Firms with a high value-to-unit share ratio are capturing their unit sales at a high relative price, while firms with a low value-to-unit ratio are winning with a low relative price. The latter situation may be worrisome, as it can indicate price is the only attribute driving company sales.

\section{Innovative capability}

A more promising non-financial output has been to examine the health of the firm's ability to innovate. As business environments change, firms must have the ability to change with them. Marketing's role in developing customer knowledge and new product concepts makes the marketing process critical in this area. Correspondingly the ability to adapt or innovate has been proposed as one of the cornerstones of marketing strategy. ${ }^{24,25}$ Firms measuring in this area have emphasised measures such as percentage of sales coming from new products and number of successful new product launches in a given time period.

Note these measures look at whether firms have been able to commercialise their innovations. This is what distinguishes measuring the marketing innovation process from simply measuring the research and development group in a firm. Having a large research and development budget is not enough for long-term success, and correspondingly measures such as $\mathrm{R} \& \mathrm{D}$ spend as a percentage of sales are of limited usefulness. Measuring the innovative capability of the firm in commercialisation terms, on the other hand, is highly useful, as it forces the firm to focus on the future product portfolio as well as the present one.

\section{THE ROLE OF MARKETING INPUTS}

Virtually all measures reviewed to this point are either measures of output or crude financial measures of input (ie how much was spent for what was obtained). One of the frustrations of marketing managers everywhere is that it is often quite difficult to demonstrate a direct causal link between their activities and sales or profit. Further, as noted previously, the sales or profit impact of current activities lies 
somewhere in the future. Given the outcome issues are therefore problematic, can something at least be said about the quality of inputs into the marketing productivity equation? The assumption underlying this approach is that if there are good marketing inputs, then eventually the money must follow.

\section{Marketing audits}

The earliest approach to input assessment, extending back to the 1950s, was the marketing audit movement. ${ }^{26}$ Analogous to an accounting audit, the idea behind this approach was to assess the health of the marketing activities within the firm. A well-cited outline in this area suggests that a good marketing audit assesses the following areas: ${ }^{27}$

- marketing environment

- marketing strategy

- marketing organisation

- marketing systems

- marketing productivity

- marketing functions.

While this outline is very reasonable, it is less clear that this is a feasible way to assess marketing performance. Done well, the process is quite intensive, and in the absence of regulatory or investor demand of the kind that requires independent accounting audits it appears quite unlikely this would become a regular measurement activity of the firm. More likely, firms might do parts of this assessment internally on a regular basis, while only bringing in a consulting firm to do a full audit in the event of a serious problem or a senior management change.

\section{Market orientation}

Related to the marketing audit, a recent substantial research stream has developed around the notion of market orientation. ${ }^{28}$ This approach focuses upon three particular marketing inputs that the disseminators of this concept consider particularly important: generation of intelligence about customers and competitors, dissemination of this intelligence within the firm, and organisational responsiveness to this information. Researchers in this area argue that a firm successful in these three areas will, in the long run, be successful in innovation and overall business performance. Evidence on the direct link between market orientation and business performance has been mixed, perhaps partially because of this implied time lag.

An interesting aspect of this approach is that one can argue that market orientation is as much an outcome of company culture as it is company behaviour. Cultivating this orientation is therefore a long-term proposition for most organisations. Various writers have suggested how to do this, ${ }^{29}$ and a number of useful measurement scales have been proposed, the best of which comes from Deshpande and Farley. ${ }^{30}$

\section{Marketing assets}

While audits and market orientation look at activities, a third input measurement approach examines what 
are called marketing assets. ${ }^{31,32}$ In this perspective, marketing activities not only help create sales and profits, but also build long-term assets that may be exploited over time, such as a loyal customer base or a powerful distribution capability. The power of brands has attracted particular attention in this area.

In accounting terms, of course, an asset is a balance sheet item, whereas most marketing activities traditionally appear on the income statement. How to value marketing assets and how to report them to interested parties is the subject of much debate. Discussion in the branding area is the most advanced. ${ }^{33}$ There is first the question of how the value of assets is realised, which typically returns to the difficult measurement issue of long-term cash flows. Secondly, 'powerful' assets can be devalued by a change in the competitive market. For example, Compaq's strong retail distribution capability was turned into a liability by the entry of direct marketers such as Dell and Gateway.

Managerially, the best approach to asset measurement is to measure changes in the health of the asset over time. For example, changes in brand awareness and attitude toward the brand within the target market can be important indicators of future marketing threats or opportunities. Trying to measure the cash value of the asset, on the other hand, is likely to be much more problematic, with the exception of customer base measurement, discussed in the following section.

\section{A REORIENTATION FROM PRODUCTS TO CUSTOMERS}

Without doubt, the strongest measurement trend in the 1990s was a move across a variety of industries from measuring the success of products to measuring the strength of customer relationships, primarily through the vehicles of customer satisfaction and loyalty. An outgrowth of work in relationship marketing and increasing technological capability, this approach follows the dictum 'don't make sales, make customers'. The focus on customers has been realised most clearly in trends toward various forms of database marketing. These trends are likely to continue in the new century.

\section{Customer satisfaction}

A large research and consulting industry has developed around customer satisfaction as a performance measure. The initial theorising in this area was both elegant and compelling: customers are satisfied to the extent that their experience with a product exceeds their expectations regarding the product. $^{34}$ More recent research has diverged in a number of directions. Most interesting from a managerial standpoint are streams that have looked at more sophisticated models of satisfaction, notably including models that separate different forms of satisfaction (eg satisfaction with the product versus satisfaction with information regarding the product). ${ }^{35}$ The intuition that satisfied customers are likely to be both loyal and profitable has proved powerful, so powerful that mixed empirical 
evidence regarding the impact of customer satisfaction on overall business performance has to some extent been ignored.

Managerially, customer satisfaction surveys have become a growth industry. The trade publication of the American Marketing Association, Marketing News, routinely lists dozens of market research firms specialising in satisfaction measurement. Best practice in this area looks at satisfaction both at an overall level and on particular attributes that are important to customers. It also reaches out to survey consumers who are not current customers of the firm, and surveys customers regarding satisfaction with competing products.

\section{Customer loyalty}

Customer loyalty research has been tied more closely to the relationship literature, database marketing, and the cash flow view point. Just as one might assess the long-term cash flow arising from a marketing strategy, the loyalty perspective claims that one should assess the cash flow arising from customer retention, usually called lifetime customer value. ${ }^{36}$ Popularised by the airline industry, promotional loyalty programmes have proliferated across a large variety of industries.

As with customer satisfaction, a compelling logic drives the loyalty perspective. Customers who are loyal are assumed to be more profitable. First, there is no acquisition cost for a current customer. Secondly, it is assumed that loyal customers are likely to be more valuable over time, through some combination of increased usage of current products, purchase of other products from the firm, or higher prices paid per product. Reichheld and his colleagues have provided the most widely cited evidence in this regard, ${ }^{37}$ but an important article by Reinartz and Kumar questions whether loyalty is desirable across all contexts. ${ }^{38}$

The most desirable customer loyalty measures are behavioural. How long is the customer relationship, how frequently does the customer buy, how recently has he or she bought, what types of products were purchased? This requires that the firm has a welldeveloped database on customers. Not surprisingly, the greatest users of customer loyalty data are industries that are both transaction- and technologyintensive enough to support this kind of database, notably airlines and financial services firms. Secondary measures of loyalty look at repurchase intention or surveys of repeat purchase rate.

Practically speaking, firms should strive to have the best database possible regarding customers. Software and expertise in this area are increasingly available. Even if calculations of lifetime customer value are difficult to estimate, the sheer value of segmenting and profiling one's customer base along the behavioural measures in the previous paragraph is enormous. Further, more direct relationships enabled by the Internet make it increasingly likely that firms across a broad spectrum of industries will be able to compile such 
Table 1

\section{SUGGESTED MEASURES OF MARKETING PERFORMANCE}

Measurement area

Sales and profitability analysis

Health of brand or company reputation ${ }^{45}$

Health of customer base

Quality of marketing inputs
Sample measures

Unit sales

Value sales

Profit/contribution

Awareness

Strength of image

Favourability of image

Uniqueness of image

Size, growth, profitability

Relative customer satisfaction

Retention rate

Frequency, recency, amount and type of purchases

Penetration of target market

Strategic activities specific to firm

Employee surveys regarding market orientation $^{46}$

$\%$ of sales from new products data. Companies that fall behind in this area may find themselves at a significant competitive disadvantage.

\section{WHAT TO DO? SUMMARY}

\section{ADVICE FOR MANAGERS}

The critical issues for managers are (1) what to measure and (2) the benchmarks against which to compare these measures.

\section{What to measure}

Fundamentally, companies should be examining their performance in terms of both immediate financial results and the health of marketing assets. Table 1 notes suggested measures in each of these areas. Measures should be used both to assess the overall business and to examine the health of particular products, markets, or distribution channels.

Sales and profitability analyses are a critical first step. Ultimately, marketing activities must contribute to the financial health of the organisation. Demonstration of the financial impact of marketing activities also establishes political credibility with the 
Figure 1: A sample product leadership strategy map

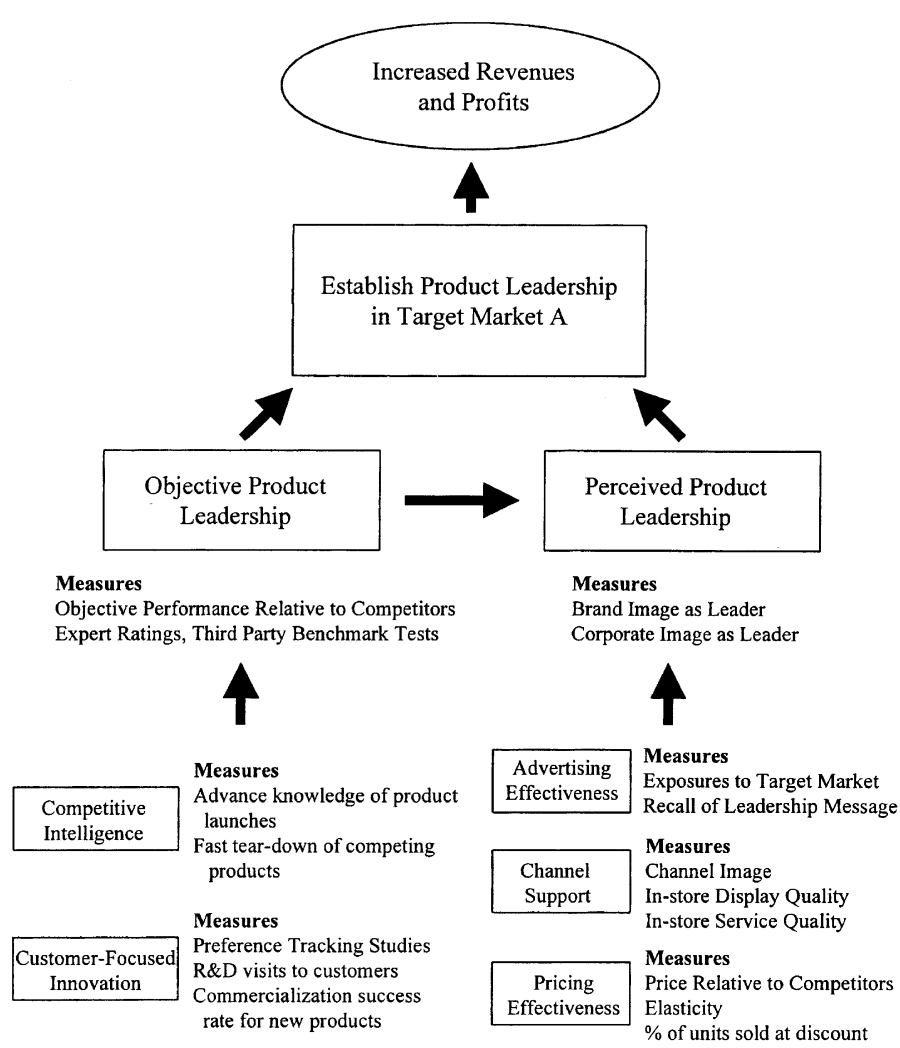

organisation's finance, accounting and budgeting arms. Any marketing plan that is missing a pro forma income statement is incomplete.

Monitor the health of marketing assets. The two most critical assets to examine are the firm or brand's reputation and the customer base. Both of these require market research regarding current, potential and former customers.

The intangible value of a strong reputation is a powerful asset for the organisation that has it. Conversely, a weak reputation is a constant drag on corporate potential. This affects not only relations with customers, but also with the investor and employee community.

Understanding the customer satisfaction and customer loyalty profile of the customer base is a very positive step for most companies; the 1990s reorientation toward customers is generally a healthy trend. Unlike sales and profit 
analysis, it can provide early warning of both threats and opportunities in the marketplace.

Track the quality of marketing activities that lead to these outcomes. While this is the most difficult measurement area, it is clear that the quality of marketing activities is a long-term concern for many firms. This has been a primary force behind the movement to discuss market-oriented behaviours and cultures. Formal marketing audits are probably too elaborate a tool for regular monitoring, but each company has critical activities that lead to both short-term sales and long-term marketing assets. These will vary across industry and organisation. One can also assess the general market orientation of the firm through internal surveys and assess the health of the firm's innovation capability.

\section{What to benchmark}

As important as specific measures is the context in which these measures are compared. Research suggests that managerial performance is usually evaluated relative to some benchmark. $^{39,40}$ Numbers are only powerful to the extent they can be compared to some baseline that indicates developing threats and opportunities. Choosing the right benchmark therefore becomes critical.

Measure performance relative to strategy. Performance should be measured relative to the target market and value proposition the organisation wishes to pursue. At a basic level, one might consider the three generic value propositions proposed by Treacy and Wiersema: ${ }^{41}$ customer intimacy, operational excellence, or product leadership. The critical activities required to deliver these value propositions differ. These activities should be measured.

A strategy map may be very helpful in this regard. ${ }^{42,43}$ This anchors upon the overall goal of the organisation (eg maximise shareholder value) and then outlines the underlying activities needed to reach this goal. Marketing activities (should) fit into overall company goals, and can be mapped as leading to this goal through execution of the marketing strategy. A typical map shows a set of activities and outcomes linked by arrows indicating which activities cause which outcomes. A sample marketing strategy map for a product leadership strategy is presented in Figure 1.

Track performance relative to competitors. One of the pervasive moderating variables proposed and documented across a variety of marketing performance measures is the competitive context. For example, high customer satisfaction is clearly a positive sign, but the payoff from satisfaction only occurs if the satisfaction level is higher than satisfaction with competing products. On a regular basis, measures should be compared to a relatively small number of key competitors for the target market(s). At less frequent intervals, it is important to step back strategically and look at a broader competitive set.

Track performance relative to customers. Strategically, tracking against customers 
involves two concerns. First, companies must be sure that they are tracking elements of market activities that actually drive customer behaviour. For example, a brand might have high favourability ratings on particular benefits, but if these are not benefits that drive behaviour they are not good measures. Competitive advantage only occurs when a company is superior at delivering benefits customers care about.

At a higher level, it is important to assess the health of the target markets in which the firm competes. This is critical to establishing whether the company is pursuing the right target markets for long-term success. A strong customer base in a declining target market represents a very different situation than a strong base in a growing one.

Track performance over time. All measures should be tracked over time as a forecasting device. Kokkinaki and Ambler $^{44}$ point out the need for examining not only changes but also changes in the rate of change to forecast where the market is headed.

Model performance. A final step once a firm has developed adequate data is to model the relationship among performance measures. This is particularly useful in informing or challenging elements of the strategy map. It might be believed, for example, that brand awareness is a critical driver of product sales. Do the data support this assumption? Modelling is particularly useful for assessing the impact of repetitive activities such as promotional scheduling or advertising exposures.

\section{CONCLUSION}

Marketing performance measurement has evolved from measures of marketing accounting and efficiency to complementary non-financial measures oriented around customer value. A comprehensive picture of marketing performance is best achieved by a combination of these measures used in the context of the organisation's strategy and customer and competitor benchmarks.

\section{REFERENCES}

1 Sheth, J. N. and Sisodia, R. S. (1995) 'Feeling the heat', Marketing Management, Vol. 4, No. 2, pp. 8-23.

2 Mavrinac, S. and Siesfeld, T. (1997) 'Measures that matter: An exploratory investigation of investors' information needs and value priorities', working paper, Ivey School of Business, University of Western Ontario.

3 Davidson, J. H. (1999) 'Transforming the value of company reports through marketing measurement,' Journal of Marketing Management, Vol. 15, No. 8, pp. 757-778.

4 Kaplan, R. S. and Norton, D. P. (1992) 'The balanced scorecard - measures that drive performance', Harvard Business Review, Vol. 70, No. 1, pp. 71-79.

5 Neely, A. (1998) 'Measuring business performance', The Economist Books, London.

6 Ambler, T. (2000) 'Marketing metrics', Business Strategy Review, Vol. 11, No. 2, pp. 59-66.

7 Marketing Science Institute (1998) '1998-2000 research priorities: A guide to MSI research programs and proce- 
dures', Marketing Science Institute, Cambridge, MA, USA.

8 Marketing Science Institute (2000) '2000-2002 research priorities: A guide to MSI research programs and procedures', Marketing Science Institute, Cambridge, MA, USA.

9 Bonoma, T. V. and Clark, B. H. (1988) 'Marketing performance assessment', Harvard Business School Press, Boston.

10 Piercy, N. (1997) 'Market-led strategic change', Butterworth-Heinemann, Oxford.

11 Ambler (2000) op. cit.

12 Sevin, C.H. (1965) 'Marketing productivity analysis', McGraw-Hill, New York.

13 Goodman, S. R. (1970) 'Techniques of profitability analysis', Wiley-Interscience, New York.

14 Shapiro, S. J. and Kirpalani, V. H. (1984) 'Marketing effectiveness: Insights from accounting and finance', Boston, Allyn and Bacon.

15 Day, G. S. and Fahey, L. (1988) 'Valuing market strategies', Journal of Marketing, Vol. 52, No. 3, pp. 45-57.

16 Clark, B. H. and Ambler, T. (2000) 'Marketing performance measurement: evolution of research and practice', in Neely, A. (ed.) 'Performance measurement - past, present and future', pp. 104-111, Centre for Business Performance, Cranfield School of Management.

17 Buzzell, R. D. and Gale, B. T. (1987) 'The PIMS principles: Linking strategy to performance', Free Press, New York.

18 Henderson, B. D. (1973) 'The ex- perience curve revisited: IV. The growth share matrix of the product portfolio', Boston Consulting Group, Boston.

19 Jacobson, R. (1988) 'Distinguishing among competing theories of the market share effect', Journal of Marketing, Vol. 52, No. 4, pp. 68-80.

20 Szymanski, D. M., Bharadwaj, S. G. and Varadarajan, P. R. (1993) 'An analysis of the market shareprofitability relationship', Journal of Marketing, Vol. 57, No. 3, pp.1-18.

21 Armstrong, J. S. and Collopy, F. (1996) 'Competitor orientation: Effects of objectives and information on managerial decisions and profitability', Journal of Marketing Research, Vol. 33, May, pp. 188-199.

22 Clark, B. H. (1998) 'Managing competitive interactions', Marketing Management, Vol. 7, No.4, pp. 9-20.

23 Mehrotra, S. (1984) 'How to measure marketing productivity', Journal of $A d$ vertising Research, Vol. 24, No. 3, pp. 9-15.

24 Walker, O. C. and Ruekert, R. W. (1987) 'Marketing's role in the implementation of business strategies: A critical review and conceptual framework', Journal of Marketing, Vol. 51, No. 3, pp. 15-33.

25 Bhargava, M., Dubelaar, C. and Ramaswami, S. (1994) 'Reconciling diverse measures of performance: A conceptual framework and test of a methodology', Journal of Business Research, Vol. 31, pp. 235-246.

26 Rothe, J. T., Harvey, M. G. and Jackson, C. E. (1997) 'The marketing audit: Five decades later', Journal of Marketing 
Theory and Practice, Vol. 5, Summer, pp. $1-16$.

27 Kotler, P., Gregor, W., and Rodgers, W. (1977) 'The marketing audit comes of age', Sloan Management Review, Vol. 18, No. 2, pp. 25-43.

28 Jaworski, B. J. and Kohli, A. K. (1993) 'Market orientation: Antecedents and consequences', Journal of Marketing, Vol. 57, No. 3, pp. 53-70.

29 Day, G. S. (1999) 'The market driven organization', Free Press, New York.

30 Deshpande, R. and Farley, J. (1998) 'Measuring market orientation: generalization and synthesis', Journal of Market-Focused Management, Vol. 2, No. 3, pp. 213-232.

31 Piercy, N. (1986) 'Marketing asset accounting: Scope and rationale', European Journal of Marketing, Vol. 20, No. 1, pp. 5-15.

32 Srivastava, R. K., Shervani, T. A., and Fahey, L. (1998) 'Market-based assets and shareholder value: A framework for analysis', Journal of Marketing, Vol. 62, No. 1, pp. 2-18.

33 Ambler, T. and Barwise, P. (1998) 'The trouble with brand valuation', The Journal of Brand Management, Vol. 5, No. 5, pp. 367-377.

$34 \mathrm{Yi}$, Y. (1990), 'A critical review of customer satisfaction', in Zeithaml, V. A. (ed.) 'Review of marketing 1990', pp. 68-123, American Marketing Association, Chicago.

35 Spreng, R. A., MacKenzie, S. B., and Olshavsky, R. W. (1996), 'A reexamination of the determinants of customer satisfaction', Journal of Marketing, Vol. 60, No. 3, pp. 15-32.
36 Wyner, G. A. (1996), 'Customer valuation: Linking behavior and economics', Marketing Research, Vol. 8, No. 2, pp. 36-38.

37 Reichheld, F. F. and Teal, T. (1996) 'The loyalty effect', Harvard Business School Press, Boston.

38 Reinartz, W. J. and Kumar, V. (2000) 'On the profitability of long-life customers in a noncontractual setting: An empirical investigation and implications for marketing', Journal of Marketing, Vol. 64, No. 4, pp. 17-35.

39 Ambler, T. and Kokkinaki, F. (2000) 'Marketing performance measurement: which way is up?' International Journal of Business Performance Management, Vol. 2, No. 1/2/3, pp. 72-85.

40 Clark, B. H. (2000) 'Managerial perceptions of marketing performance: Efficiency, adaptability, effectiveness, and satisfaction', Journal of Strategic Marketing, Vol. 8, No. 1, pp. 3-25.

41 Treacy, M. and Wiersema, F. (1995) 'The discipline of market leaders', Addison-Wesley, Reading, MA.

42 Kaplan R. S. and Norton, D. P. (2000) 'Having trouble with your strategy? Then map it', Harvard Business Review, Vol. 78, No. 5, pp. 167-176.

43 Neely (1998) Ch. 6, op. cit.

44 Kokkinaki, F. and Ambler, T. (1999) 'Marketing performance assessment: An exploratory investigation into current practice and the role of firm orientation', Marketing Science Institute Working Paper, pp. 99-114.

45 See Keller (1998), op. cit.

46 See Deshpande and Farley (1998) op. cit. 